\title{
DYNAMIC SOIL-STRUCTURE INTERACTION OF DUCTILE STEEL FRAMES IN SOFT SOILS
}

\author{
Edgar Tapia-Hernández ${ }^{1, *}$, Yesenia De Jesús-Martínez ${ }^{1}$ and Luciano Fernández Sola ${ }^{1}$ \\ ${ }^{1}$ Materials Department, Universidad Autónoma Metropolitana - Azcapotzalco. Mexico City. \\ *(Corresponding author: E-mail: etapiah@hotmail.com)
}

Received: 7 June 2016; Revised: 27 August 2016; Accepted: 26 October 2016

\begin{abstract}
Results of static and dynamic nonlinear analysis of ductile steel frames of 8- and 12- stories buildings are discussed in this paper. The influence of dynamic soil-structure interaction in deformation demands, failure mechanism, ductility and overstrength capacities and maximum demands in columns were analyzed. For this purpose, buildings were designed and studied under three boundary conditions: (i) fixed-base (no Soil-Structure Interaction), (ii) pile foundation and (iii) mat foundation condition. The influence of the lateral stiffness was studied through the response of moment resisting frames (unbraced frames), 1-braced bay frames and 2-braced bays frames. Soil foundation dynamic stiffness (impedance function) is introduced by a set of springs in horizontal and rocking direction, which were computed from the dynamic behavior and properties of the soil-foundation system. It was found that fixed base model might not be a conservative representation of the response of buildings with flexible foundations, especially when a pile foundation system is considered.
\end{abstract}

Keywords: Steel frames, inelastic analyses, pile foundation, mat foundation, soft soil

DOI: $10.18057 / \mathrm{IJASC} .2017 .13 .4 .3$

\section{INTRODUCTION}

Most of the design procedures in current seismic codes are based on elastic analyses and account the inelastic response in an indirect way. In many codes (such as Mexico's Federal District Code MFDC-04 [1] and ASCE/SEI 7-05 [2]), the lateral load patterns along the height of building depend on the fundamental period and their masses (Ganjavi and Hao [3]). In these codes, the load pattern is obtained by elastic analysis under a fixed-base condition, neglecting the possible effects of soil-foundation flexibility. The effectiveness of this procedure has been widely studied. In general, it is concluded that the ductility demands are not the same and in many cases the collapse mechanism is led by the first floor.

Results of nonlinear dynamic analysis suggest that models designed by following general guidelines do not adjust acceptably with the assumptions inherent to the design philosophy. Structures designed under a ductile behavior philosophy could have near-elastic responses and important overstrength reserves that are not necessarily considered in the design process (Tapia-Hernández and Tena-Colunga [4]). Therefore, the employment of the normative load patterns does not guarantee the optimum use of materials in regular buildings. An adjustment of the load pattern is necessary with respect to the period of the structure and the target ductility demand (Moghaddam and Hajirasouliha [5]).

In addition, seismic designs for soil-structure interaction (SSI) are based on an approximation in which the predominant period (and associated damping) of the corresponding fixed-base system are modified $[1,6,7]$. In fact, the current seismic provisions consider that the soil-structure interaction is a beneficial effect, since it usually causes a reduction of total base shear. However, in soft soil, the fundamental period of the building with fixed base might be located in the region of the ascending branch of the design spectra and, therefore, SSI might increase the acceleration demand, even despite the possible increase of the structure's damping. 
In recent years, the influence of the SSI under inelastic analysis has been studied through single-degree-of-freedom systems (Rosenblueth and Reséndiz [8], Avilés and Pérez-Rocha [9]) or through simplified models in 2D (Tabatabaiefar et al. [10], Sáez et al. [11]); while the interaction on inelastic response of multi-degrees-of-freedom systems, which is more complex, has not been widely investigated (Ganjavi and Hao [12]). In fact, just a few studies of SSI on multi-degrees-of-freedom systems have been conducted (Barcena and Esteva [13], Raychowdhury [14], Fernández-Sola et al. [15]).

In this paper, the inelastic response of buildings structured with ductile steel frames was studied, in order to evaluate the influence of the foundation flexibility. Models represent typical regular mid-rise building frames in Mexico City. Buildings were evaluated through multi-degree-of-freedom systems under pushover and nonlinear time-history analysis. The dynamic analysis is performed by a set of selected historical ground motion related to the corresponding design spectrum. In addition, the influence of the lateral stiffness was also evaluated. For this purpose, the results of the analysis of moment resisting frames (unbraced frames), frames with one braced bay and frames with two braced frames are discussed.

\section{DESCRIPTION OF MODELS}

Buildings of 8- and 12- stories were designed for soft-soil site conditions (lake zone of Mexico City) and a ductility factor $\mu=3.0$, which is the maximum allowed for these structures according to MFDC-04 [1]. The buildings were representative of typical office buildings structured with ductile moment-resisting concentrically braced frames (MRCBFs) with three frame configurations: unbraced frames, internal frames with one braced bay and external frames with two braced bays as shown in Fig 1b. The design gravity loads for the studied models are also given in Figure 1.

Buildings were designed using 3-D models (Figure 1c) with the response spectrum analysis of MFDC-04 [1]. The resisting elements were designed by applying standard capacity concepts for ductile systems through an iterative process. Here, the following sequence was used for the member design: the bracing system, beams, columns and panel zone connection. The final sections for all models are summarized in Table 1 and reported in further detail in Tapia-Hernández [16].

According to MFDC-04 [1], a ductile braced frame should be designed using a representative analytical model, where a maximum shear strength balance between the resisting frames and the bracing system shall be considered. At all stories, the frames should be able to resist at least 50 percent of the seismic shear force without the contribution of bracing system. Moment resisting concentrically braced frames were designed to meet the lateral shear strength balances between the bracing system itself and the corresponding columns of the moment frame. Further information on the design process can be found in Tapia-Hernández and Tena-Colunga [17]. 


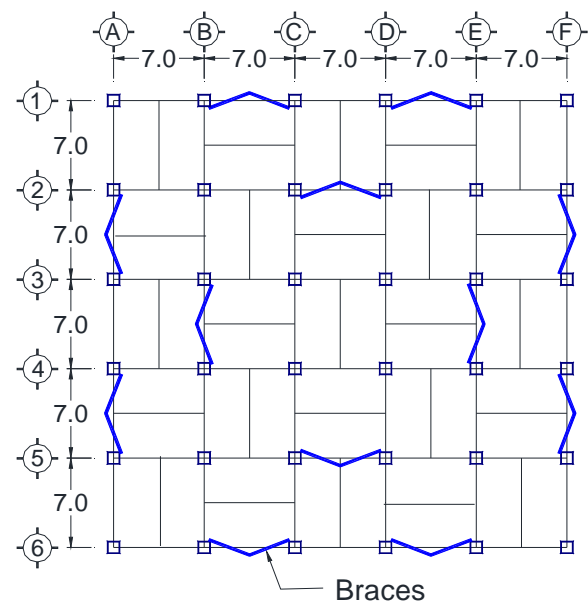

a) Typical floor plan view
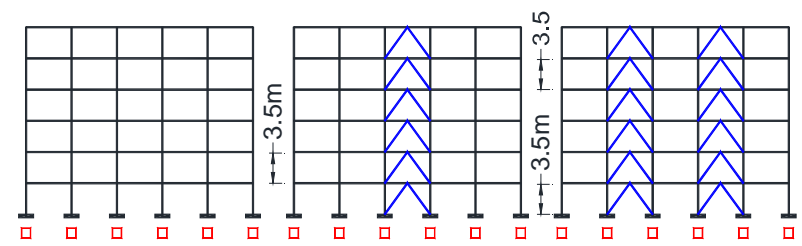

b) Typical elevations: Unbraced frame, Internal CBF 1-braced bay, Perimeter CBF 2-braced bay

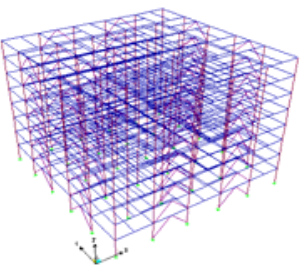

c) 3-D model

$\begin{array}{rr}\text { Floor Dead } & 5.98 \mathrm{kN} / \mathrm{m}^{2} \\ \text { Roof } & 5.34 \mathrm{kN} / \mathrm{m}^{2} \\ \text { Dead } & \\ \text { Floor Live } & 2.45 \mathrm{kN} / \mathrm{m}^{2} \\ \text { Roof Live } & 0.98 \mathrm{kN} / \mathrm{m}^{2}\end{array}$

Figure 1. Buildings

Table 1. Designed Sections for the Studied Models

\begin{tabular}{|c|c|c|c|}
\hline Model & Element & Stories & Cross section $(\mathrm{cm})$ \\
\hline \multirow{7}{*}{$\begin{array}{l}8 \text {-story } \\
\text { building }\end{array}$} & \multirow{3}{*}{$\begin{array}{l}\text { Column } \\
\text { Rectangular box section }\end{array}$} & S1 to S3 & $40 \mathrm{x} 40 ; t=1.91 \mathrm{~cm}(3 / 4 ")$ \\
\hline & & S4 to S6 & $40 \times 40 ; t=1.58 \mathrm{~cm}(5 / 8 ")$ \\
\hline & & $\mathrm{S} 7$ to $\mathrm{S} 8$ & $40 \times 40 ; t=1.27 \mathrm{~cm}(1 / 2 ")$ \\
\hline & Beams & S1 to $S 2$ & W $18 "$ x $128.1 \mathrm{~kg} / \mathrm{m}$ \\
\hline & W-steel section & $\mathrm{S} 3$ to $\mathrm{S} 8$ & W $18 " \times 112.9 \mathrm{~kg} / \mathrm{m}$ \\
\hline & Braces & $\mathrm{S} 1$ to $\mathrm{S} 4$ & $15 \times 15 t=0.95 \mathrm{~cm}\left(3 / 8^{\prime \prime}\right)$ \\
\hline & Rectangular box section & $\mathrm{S} 5$ to $\mathrm{S} 8$ & $15 \times 15 t=0.64 \mathrm{~cm}\left(1 / 4^{\prime \prime}\right)$ \\
\hline \multirow{9}{*}{$\begin{array}{l}\text { 12-story } \\
\text { building }\end{array}$} & \multirow{4}{*}{$\begin{array}{l}\text { Column } \\
\text { Rectangular box section }\end{array}$} & S1 to $\mathrm{S} 3$ & $45 \times 45 ; t=2.22 \mathrm{~cm}(7 / 8 ")$ \\
\hline & & $\mathrm{S} 4$ to $\mathrm{S} 6$ & $45 \times 45 ; t=1.90 \mathrm{~cm}(3 / 4 ")$ \\
\hline & & $\mathrm{S} 7$ to $\mathrm{S} 8$ & $45 \times 45 ; t=1.58 \mathrm{~cm}(5 / 8 ")$ \\
\hline & & $\mathrm{S} 9$ to $\mathrm{S} 12$ & $45 \times 45 ; t=1.27 \mathrm{~cm}(1 / 2 ")$ \\
\hline & Beams & S1 to $\mathrm{S} 3$ & IR 18"x157.8 kg/m \\
\hline & W-steel & $\mathrm{S} 4$ to $\mathrm{S} 12$ & IR $18 " x 144.3 \mathrm{~kg} / \mathrm{m}$ \\
\hline & \multirow{3}{*}{$\begin{array}{l}\text { Braces } \\
\text { Rectangular box section }\end{array}$} & $\mathrm{S} 1$ to $\mathrm{S} 4$ & $25 \times 25 t=2.22 \mathrm{~cm}\left(7 / 8^{\prime \prime}\right)$ \\
\hline & & $\mathrm{S} 5$ to $\mathrm{S} 8$ & $25 \times 25 t=1.91 \mathrm{~cm}(3 / 4 ")$ \\
\hline & & $\mathrm{S} 9$ to $\mathrm{S} 12$ & $25 \times 25 t=1.58 \mathrm{~cm}\left(5 / 8^{\prime \prime}\right)$ \\
\hline
\end{tabular}

For the models with flexible base (SSI), two foundation systems were proposed: a partially compensated mat foundation and a pile foundation. Here, compensation corresponds to the difference between the total weight of the building and the resistance of the foundation slab behaving as a shallow foundation. Whereas floating circular piles (with diameter of $0.40 \mathrm{~m}$ ) were considered for pile foundation. The particular design characteristics are discussed in the following section.

The frames of the building were decoupled in order to study the influence of the lateral stiffness on the inelastic response. The cryptograms for the identification of the models are $x y z$, where $x$ indicates the base condition: $F$ for a fixed-base boundary, $P$ for a pile foundation and $M$ for a mat foundation; $y$ indicates the number of stories ( 08 or 12$)$ and $z$ indentifies the number of braced bays, 0 for unbraced frame, 1 for 1-bay braced frame and 2 for 2-bay braced frames (Figure 1b). 


\subsection{Characteristics of the Foundation}

Soil properties were obtained from a downhole and suspension logging test of a typical cohesive soil $\left(c=50.0 \mathrm{kN} / \mathrm{m}^{2}\right)$ of the Lake Zone of Mexico City. Soil was modeled as a homogeneous layer with thickness $H_{s}=40 \mathrm{~m}$, shear wave velocity $V_{s}=65 \mathrm{~m} / \mathrm{s}$, unit weight $\gamma=13 \mathrm{kN} / \mathrm{m} 3$, Poisson ratio $v=0.50$ and damping ratio $\xi=0.05$. Thus, the foundation was designed following a resistance based design described in the MFDC-04 [1] for each flexible base system (Table 2). Further information about the characteristics of the soil and foundations can be found in Dávalos [18].

Table 2. Foundation Properties and Impedance Values

\begin{tabular}{|c|c|c|c|c|c|c|c|}
\hline \multirow[b]{2}{*}{ Building } & \multicolumn{3}{|c|}{ Mat foundation } & \multicolumn{4}{|c|}{ Piles } \\
\hline & $\begin{array}{l}\text { Depth } \\
\text { (m) }\end{array}$ & $\begin{array}{c}K_{h} \\
(\mathrm{kN} / \mathrm{m})\end{array}$ & $\begin{array}{c}K_{r} \\
(\mathrm{kN} / \mathrm{m})\end{array}$ & $\begin{array}{l}\text { No. of } \\
\text { piles }\end{array}$ & $\begin{array}{l}\text { Length } \\
\text { (m) }\end{array}$ & $\begin{array}{c}K_{h} \\
(\mathrm{kN} / \mathrm{m})\end{array}$ & $\begin{array}{c}K_{r} \\
(\mathrm{kN} / \mathrm{m})\end{array}$ \\
\hline 8-story & 4.0 & $1.203(10)^{6}$ & $8.931(10)^{7}$ & 121 & 20.0 & $1.180(10)^{6}$ & $7.330(10)^{8}$ \\
\hline 12-story & 9.0 & $1.423(10)^{6}$ & $2.792(10)^{8}$ & 169 & 22.0 & $9.352(10)^{5}$ & $3.330(10)^{8}$ \\
\hline
\end{tabular}

Usually the dynamic behavior of the foundation is characterized by a complex-valued dynamic function commonly referred as the massless compliance function, which is defined as the ratio of the displacement response and the total load at the soil-foundation interface as a function of the frequency (Jafarzadeh and Asadinik [19]). The inverse of the compliance function is called impedance function and it is computed from the geometrical properties. Impedance functions (Eq. 1) are the dynamic stiffness of soil-foundation system. They are defined as the dynamic force (or moment) needed to produce a unitary displacement (or rotation) in the massless foundation.

$\check{K}(\omega)=K(\omega)+i \omega C(\omega)$

In Eq. 1, the real part $K(\omega)$ represents the inertia and stiffness of soil-foundation system. The imaginary part $C(\omega)$ represents the amount of energy dissipated by either wave radiation or histeretical behavior of the soil. Since the definition of the impedance functions considers that the soil-foundation system are performing together, the representation of soil-foundation stiffness and damping is done by a set of equivalent springs on the base of the building (Figure 2).

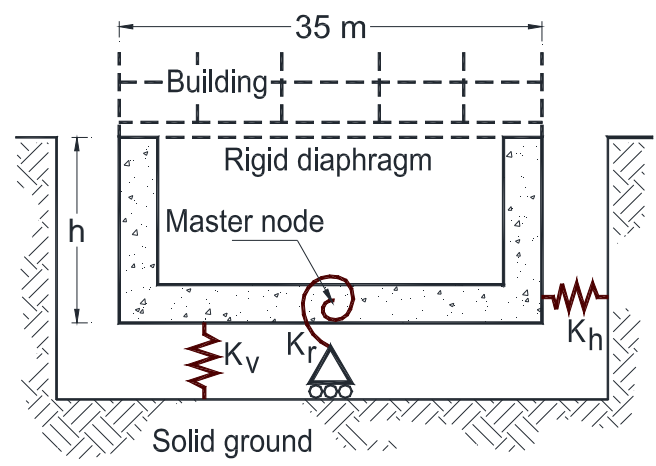

a) Impedance functions as a set of equivalent springs

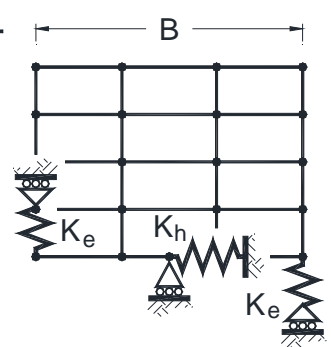

b) Boundary displacements

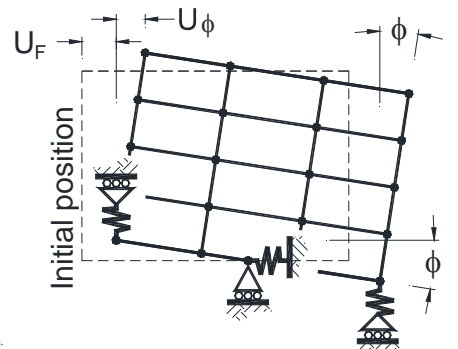

conditions and related

Figure 2. Models with Flexible Foundation

Mexico City is placed on a thick layer of soft clay deposits over a hard stratum, located on the edge of an old lakebed. In the lake-bed area, the shear wave velocity of the soft clay varies from 40 to $90 \mathrm{~m} / \mathrm{s}$. Because of this, shear seismic waves experience an important vertical polarization, producing a mainly horizontal surface motion. Under these conditions, the rocking stiffness of the soil-foundation system and, specially, the horizontal stiffness have an important influence on the 
structural behavior of flexible buildings. In contrast, the vertical response and, in consequence, the vertical stiffness is less important under lateral demands. This is characteristic not only for the local soil conditions of Mexico City, but also of all soft soils.

Thus, an infinite vertical stiffness was considered $\left(K_{v} \rightarrow \infty\right)$; in fact, the vertical component of ground motion was neglected. Horizontal $K_{h}$ and rocking $K_{r}$ stiffness were computed with Dyna5 [20]. Mat foundation was modeled as stratumfoundation in Dyna5, which is a model of raft embedded in an homogeneous finite layer. Piles were modeled with pile foundation as flexible elements with pinned tip and a fixed head boundary condition; this model allows the study of group effects. The values obtained by the impedance functions for the fundamental frequency were also included in Table 2.

In the models, the rotational stiffness $K_{r}$ was modeled by equivalent vertical springs $K_{e}$ (Figure 3 ). The strategy to compute the stiffness of the equivalent spring $K_{e}$ is through the sum of the moments about A (Eq. 2).

$\Sigma M_{A}=0 \quad F_{e}(B / 2)+F_{e}(B / 2)-M_{r}=0$

Where, $B$ is the building's width (=35 m, Figure $2 \mathrm{a}) ; F_{e}$ is the axial force of the equivalent spring, which is equal to $F_{e}=K_{e} d_{e}$ and $M_{r}$ is the moment at the point A, which is equal to $M_{r}=K_{r} \phi$. Here, $K_{e}$ is the stiffness of the equivalent spring; $K_{r}$ is the rotational stiffness; $\phi$ is the base rotation and $d_{e}$ is the axial shortening of the equivalent spring (Figure 3 ). Then, the equation of moment equilibrium becomes equal to Eq. 3 .

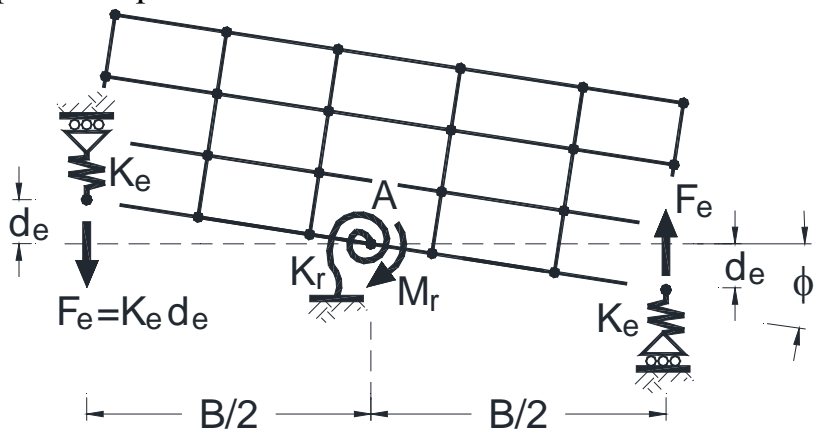

Figure 3. Definition of Variables

$2\left[K_{e} d_{e}\right](B / 2)-\left[K_{r} \phi\right]=0$

Additionally, from trigonometry the rotation is equal to $\phi=d_{e} /(B / 2)$, which is approximately true in the limit where the angle $\phi$ approaches to zero. The stiffness of the equivalent spring $K_{e}$ can be computed by the Eq. 4, as a function of the rotational stiffness $K_{r}$.

$K_{e}=K_{r} /\left(2(B / 2)^{2}\right)$

\section{NONLINEAR STATIC ANALYSIS}

Pushover analyses were carried out using the Drain-2DX computer program [21]. The elements were modeled with an inelastic response and P-delta effects were considered. An inverted triangular lateral load pattern was used, which is consistent with the static method of seismic analysis established in MFDC-04 [1]. 
Structural displacements of the fixed base model $U_{S}$ are related exclusively with the deformations of the building. Moreover, models with flexible foundation are also related with two additional components: $(i)$ the displacement associated with the foundation rocking $U_{\phi}$ and (ii) the base translation $U_{F}$, as shown in Figure 2b (Eq. 5).

$U_{T}=U_{S}+U_{F}+U_{\phi}$

Pushover curves by interstory of the 12-story building with 2-braced frames (F122, P122 and M122) are shown in Figure 4. According to the results, fixed-base frames are stiffer than the ones with flexible foundation. For this reason, a smaller lateral displacement was developed by the models without SSI. However, the large displacement of models with flexible-base (P122 and M122) should not be interpreted as the structures are subjected to a larger demand than the one computed for the fixed-base models. The lateral excitations are equivalent between them as it is discussed below.
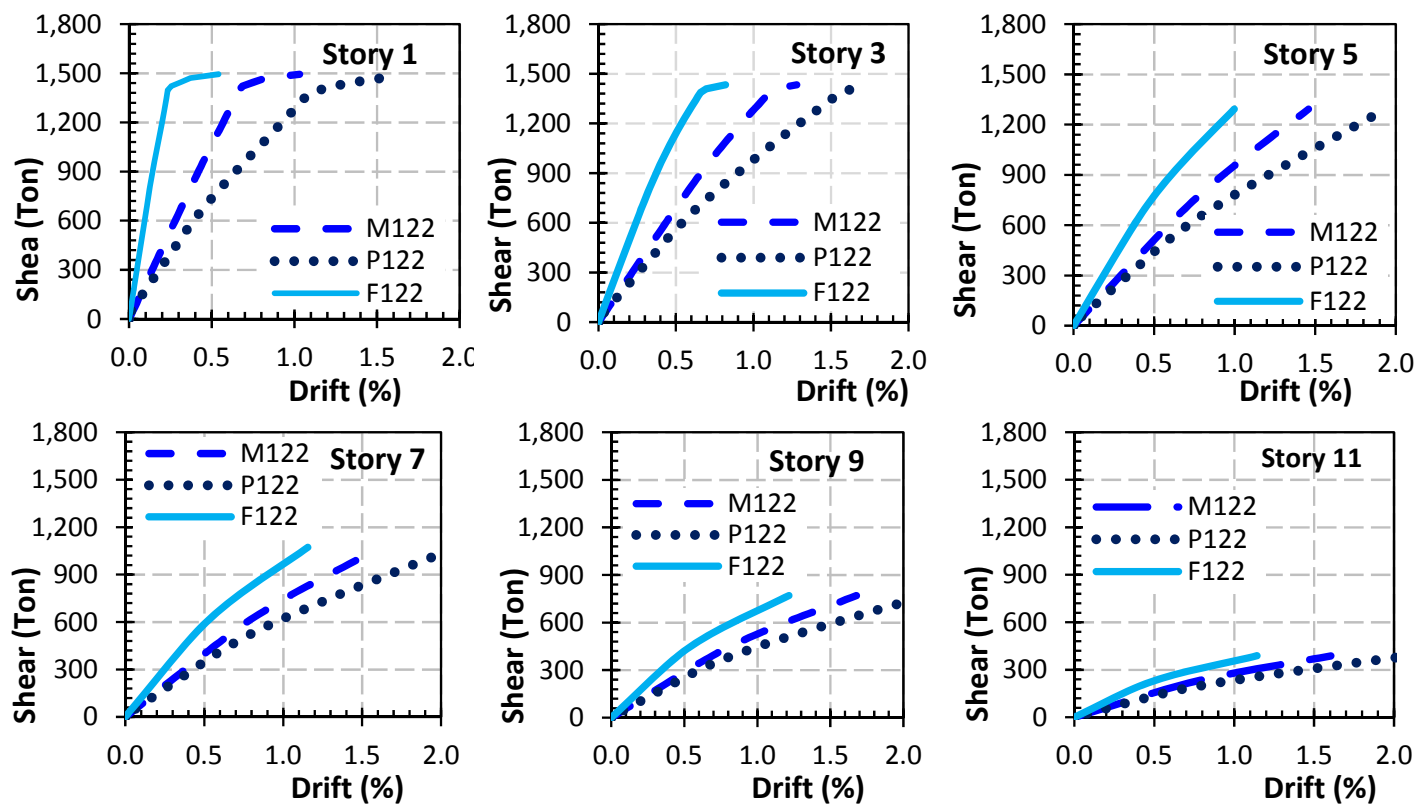

Figure 4. Capacity Curves of 2-bay Braced Frames of the 12-story Building

The global drift (deformation between the roof and base divided by the height) at initial yielding $\delta_{y}$ and the final drift $\delta_{u}$ related to the collapse mechanism were computed from pushover curves (Table $3)$. According to the results, the total displacements of flexible-foundation models $\left(U_{S}+U_{F}+U_{\phi}\right)$ are significantly larger than the fixed-base ones. However, the demands are similar when only structure deformations are compared (the foundation rocking $U_{\phi}$ and base translation $U_{F}$ components were removed).

Additionally, in order to identify the contribution of each displacement component ( $U_{S}, U_{F}$ and $U$ ) to the total displacements in the flexible-base models, the displacement normalized with the total displacement $U_{T}$ was also computed (Table 3). It was found that the base translation component $U_{F}$ has a small influence in the displacement, it represents between $6 \%$ and $10 \%$ of the total displacement $U_{T}$. In contrast, the foundation rocking component represents between $52 \%$ and $56 \%$ of the displacement originally obtained from the analysis $U_{T}$. This implies that the displacement component associated with the base rotation $U_{\phi}$ is the largest contribution in flexible base models. It is worth mentioning that the stiffer frame (2-braced bays) with pile foundation (P122C) does not follow this trend, but the main contribution is related to the structure deformation predominantly Us. 
Tabla 3.Global Drift obtained for the 12-story Buildings

\begin{tabular}{|c|c|c|c|c|c|c|c|c|}
\hline \multirow{2}{*}{$\begin{array}{c}\text { Foundation } \\
\text { model }\end{array}$} & \multirow{2}{*}{ Deformation } & \multirow{2}{*}{ Model } & \multicolumn{3}{|c|}{ Yielding } & \multicolumn{3}{|c|}{ Collapse } \\
\hline & & & $\delta_{y}(\%)$ & Step & $U / U_{T}(\%)$ & $\delta_{u}(\%)$ & Step & $U / U_{T}(\%)$ \\
\hline \multirow{3}{*}{\begin{tabular}{l}
\multicolumn{1}{c}{ a) } \\
Fixed-base \\
model
\end{tabular}} & \multirow{3}{*}{$\begin{array}{l}\text { Structure, } \\
U_{S}\end{array}$} & F120 & 0.51 & 09 & --- & 0.86 & 11 & $-\cdots$ \\
\hline & & F121 & 0.41 & 21 & $-\ldots$ & 1.02 & 37 & - \\
\hline & & F122 & 0.31 & 26 & -- & 1.01 & 61 & $-\ldots$ \\
\hline \multirow{18}{*}{$\begin{array}{l}\quad \text { b) } \\
\text { Flexible } \\
\text { foundation } \\
\text { model }\end{array}$} & \multirow{3}{*}{$\begin{array}{l}\text { Total, } \\
U_{T}=U_{S}+U_{F}+U_{\phi}\end{array}$} & P120 & 0.95 & 09 & 100.0 & 1.46 & 11 & 100.0 \\
\hline & & P121 & 0.78 & 21 & 100.0 & 1.70 & 37 & 100.0 \\
\hline & & P122 & 0.50 & 22 & 100.0 & 1.90 & 60 & 100.0 \\
\hline & \multirow{3}{*}{$\begin{array}{l}\text { Results of } \\
\text { pushover analyses }\end{array}$} & M120 & 0.92 & 09 & 100.0 & 1.41 & 11 & 100.0 \\
\hline & & M121 & 0.75 & 21 & 100.0 & 1.65 & 37 & 100.0 \\
\hline & & M122 & 0.56 & 26 & 100.0 & 1.62 & 61 & 100.0 \\
\hline & \multirow{4}{*}{$\begin{array}{l}\text { Structure and } \\
\text { foundation } \\
\text { rocking, } U_{S}+U_{\phi}\end{array}$} & P120 & 0.89 & 09 & 93.7 & 1.39 & 11 & 95.2 \\
\hline & & $\mathrm{P} 121$ & 0.73 & 21 & 93.6 & 1.61 & 37 & 94.7 \\
\hline & & $\mathrm{P} 122$ & 0.50 & 22 & 100.0 & 1.90 & 60 & 100.0 \\
\hline & & M120 & 0.83 & 09 & 90.2 & 1.30 & 11 & 92.2 \\
\hline & \multirow{2}{*}{$\begin{array}{l}\text { (No base } \\
\text { translation } U_{F} \text { ) }\end{array}$} & M121 & 0.67 & 21 & 89.3 & 1.52 & 37 & 92.1 \\
\hline & & M122 & 0.50 & 26 & 89.3 & 1.48 & 61 & 91.4 \\
\hline & \multirow[t]{2}{*}{ Structure, $U_{S}$} & P120 & 0.52 & 09 & 54.7 & 0.93 & 11 & 63.7 \\
\hline & & P121 & 0.41 & 21 & 52.6 & 1.05 & 37 & 61.8 \\
\hline & \multirow{4}{*}{$\begin{array}{l}\text { (No base } \\
\text { translation } U_{F} \text { nor } \\
\text { foundation } \\
\text { rocking } U_{\phi} \text { ) }\end{array}$} & P122 & 0.45 & 22 & 90.0 & 1.77 & 60 & 93.2 \\
\hline & & M120 & 0.52 & 09 & 56.5 & 0.92 & 11 & 65.2 \\
\hline & & M121 & 0.41 & 21 & 54.7 & 1.05 & 37 & 63.6 \\
\hline & & M122 & 0.31 & 26 & 55.4 & 1.02 & 61 & 63.0 \\
\hline
\end{tabular}

Pushover global curves (base shear against global drift) of the studied models are shown in Figure 5. The unbraced frames and the 1-braced bay frames of the 12-stories building with flexible foundation (P120C, CC120C, P121C and CC121C) develop a similar response. However, the 2-braced bay frame with pile foundation (P122C) develops a larger displacement. This increase might be related to further damage of structural elements, because of the fact that the main displacement component is associated with the structure deformation (Table 3).
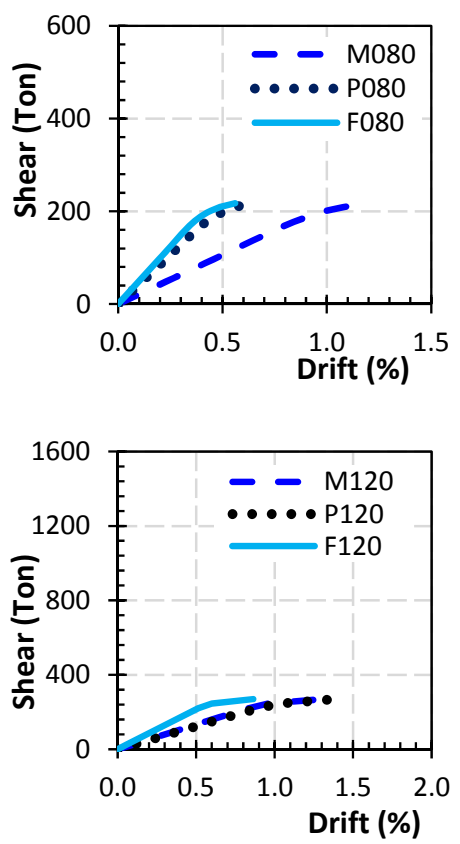

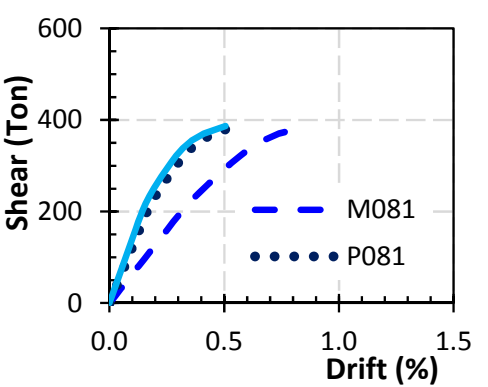

a) 8-story model

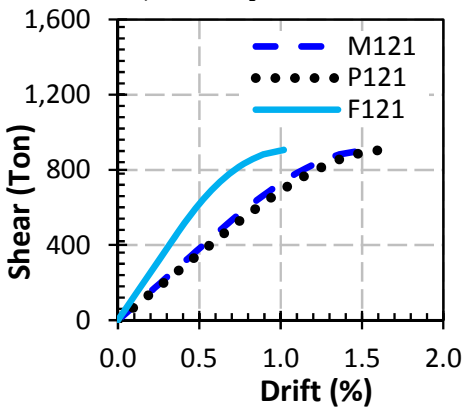

b) 12-story model
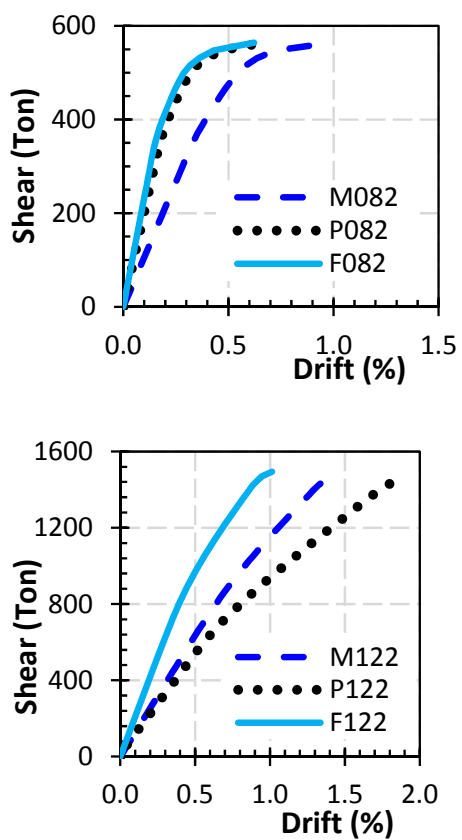

Figure 5. Pushover Global Curves 
In contrast, the response of the 8-story frames with pile foundation ( $\mathrm{P} 080, \mathrm{P} 081$ and $\mathrm{P} 082)$ is similar to those developed by the fixed-base model (F080, F081 and F082). This is due to the group effect of the piles, which increases the stiffness of the soil-foundation system, in spite of the fact that the 8 -story model has fewer piles than the 12-story model (Table 2).

In piles foundation, the stiffness of the group of piles is not necessarily equal to the sum of the individual stiffness of each element. In fact, due to the dynamic nature of the demand, the group effect might increase the stiffness of the foundation system (Dobry and Gazetas [22]). Thus, the increment of the stiffness is related primarily to dynamic nature of the impedance functions. If the analyzed frequency $n$ corresponds to an anti-resonant frequency of the piles group; then the displacements would be reduced and, therefore, the group response would be stiffer.

The rocking stiffness of the pile foundation was computed in Dyna5 [20] for the studied buildings (Figure 6). There, the group effect was considered according to the method developed by Dobry and Gazetas [22].

For the quasi-static case $(n \approx 0.0)$, the rocking stiffness is approximately $K_{r}=6.1(10)^{11} \mathrm{kN} / \mathrm{m}$ in both cases (Figure 6), regardless the amount of piles. This is due to the quasi-static rocking stiffness depends only on the distance between the external piles. Thus, buildings might develop an equivalent response for frequencies less than $n<7.0 \mathrm{rad} / \mathrm{sec}$. For higher frequencies, the dynamic interaction between individual piles becomes different due to the group effect. Rocking stiffness increases as the frequency increases for the 8-story building. And for the 12-story building, the interaction among wave fields produced by the individual piles decrease the stiffness. In Figure 6 , the fundamental frequencies of the models $\left(n_{08}=15.7 \mathrm{rad} / \mathrm{sec}\right.$ and $\left.n_{12}=12.6 \mathrm{rad} / \mathrm{sec}\right)$ are included, in order to point out that the computed rotational stiffness for the 8-story building is almost twice as the one calculated for the 12-story building.

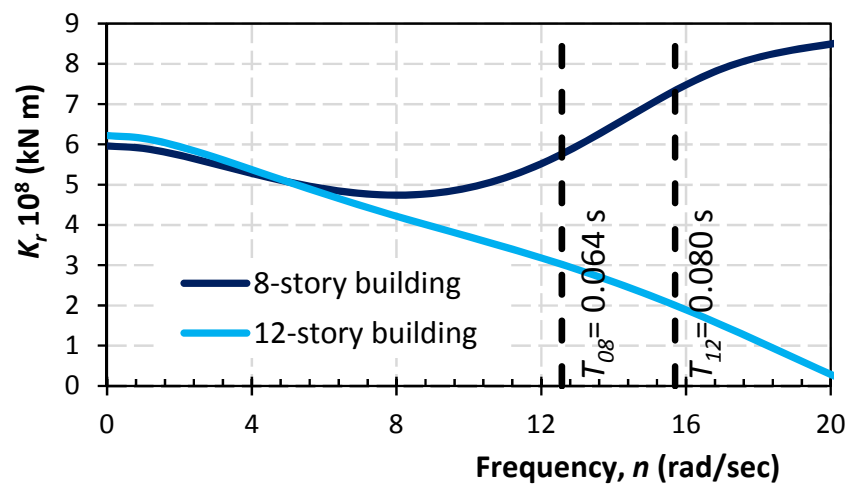

Figure 6. Rotational Stiffness $K_{r}$ of the Pile Foundation Models 
In fact, the group effect was also noticeable in the obtained pushover curves of the 8-story frames (Figure 7). Significant differences between the responses of the flexible base models were obtained. So, group effect might modify the overall stiffness of flexible base models. For some particular design conditions and models with piles foundation, flexible base models might become as stiffer as the fixed-base models. Additionally, it is worth mention that upper stories have near-elastic responses and important overstrength reserves, as it is discussed in the following section.
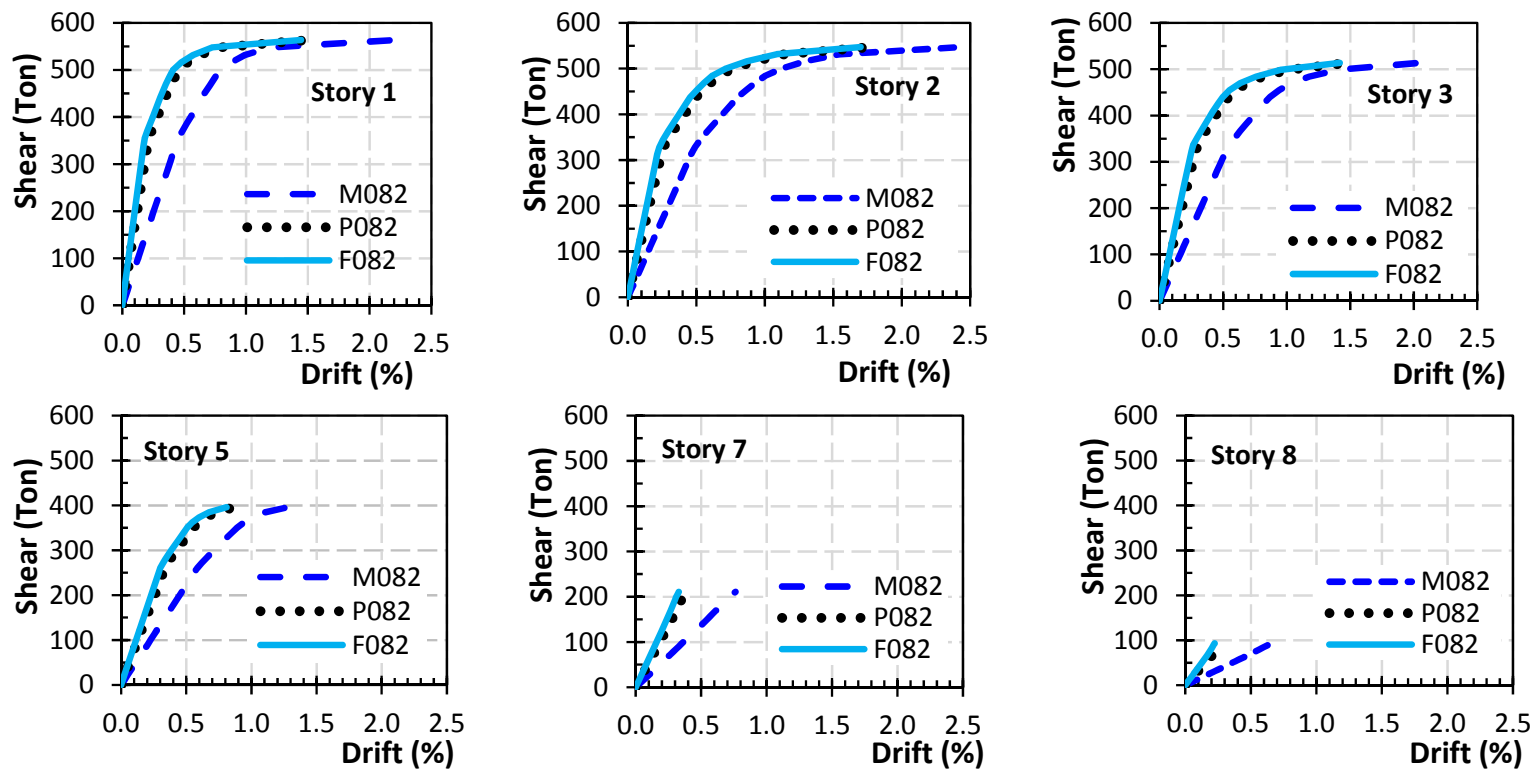

Figure 7. Pushover Curves of the 8-story Frame with 2-braced Bays

\section{COLLAPSE MECHANISMS}

Collapse mechanisms of the 2-braced bays frames (F122, P122 and M122) are presented in Figure 8. Magnitudes of inelastic deformations are shown with a color scale. They are normalized in relation with the maximum yielding rotation in beams and columns or axial extension and axial shortening in braces. In the braced bays, the brace in the left side is in tension with axial extensions, while the brace in the right side is in compression with axial shortenings. In each case, the step and the global drift were also included.

According to the results, besides the plastic hinges at beams, some plastic hinges have developed at column ends with fewer braces buckle at the collapse mechanism (Figure 8). This suggests a near soft story collapse mechanism with no uniform distribution of yielding within the height. The collapse mechanism is completely different from the one assumed in the design process (strong column - weak beam - weaker brace mechanism). In fact, results of recent research regarding braced frames (Tapia-Hernández and Tena-Colunga [4], Lacerte and Tremblay [23]) conclude that following current building codes, final collapse mechanism do not necessarily agree in many instances with the initial design assumptions in rational analyses of buildings. In addition, no dependency was observed between this trend and the modeled base condition. 


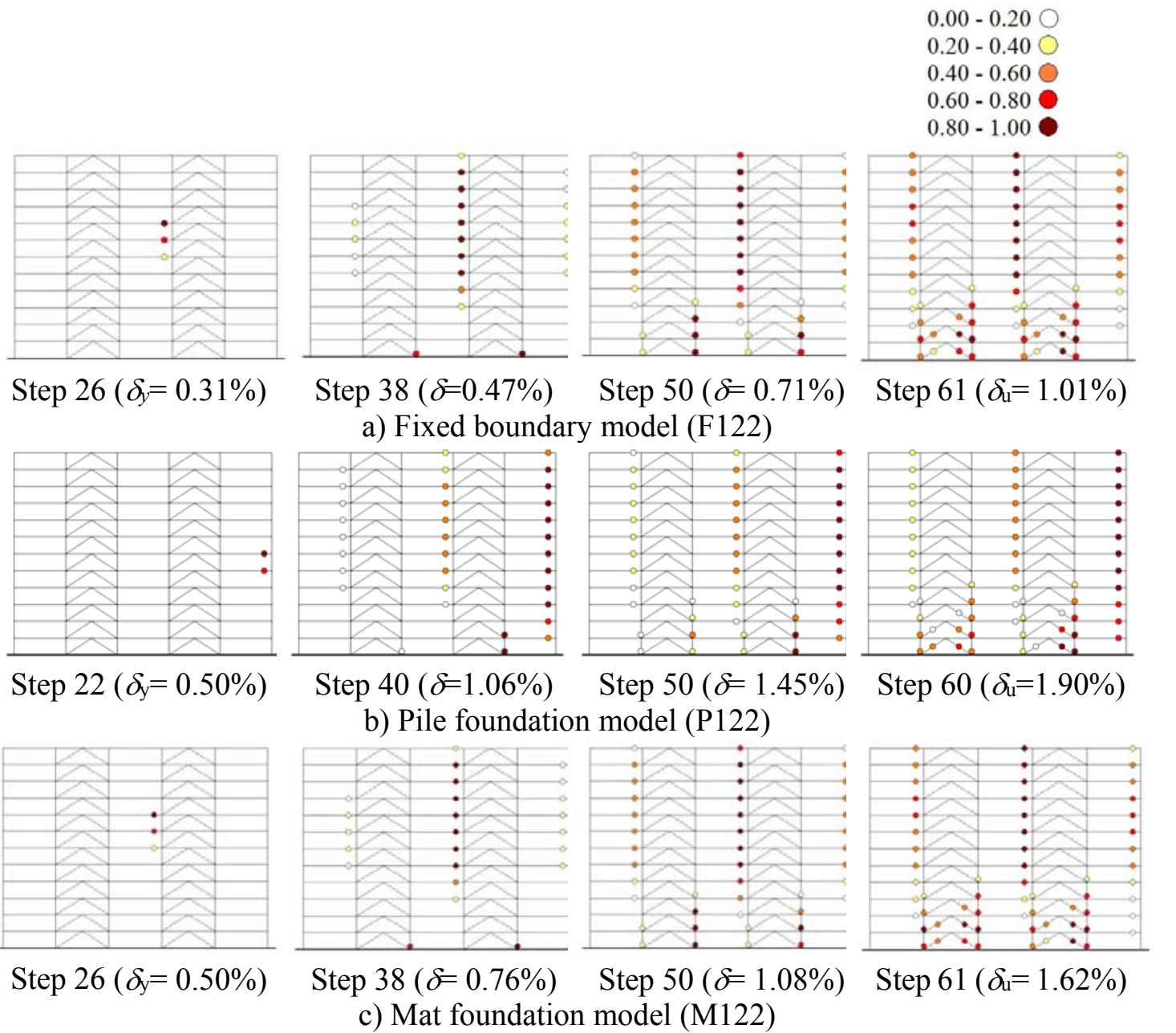

Figure 8. Behavior of 2-braced Bay Model along the Pushover Analysis

The deformation demands at the collapse mechanism were also studied. Average values of ultimate drifts are close to the Code's limit equal to $1.5 \%$ [1] for buildings structured with concentrically braced steel frames (Figure 9). Therefore, the normative deformation limit seems adequate for practical purposes as it was shown in similar studies (Tapia-Hernández and Tena-Colunga [24]). Considering this results, the developed ductility and overstrength for each frame are reported in the following section. 
Unbraced frame
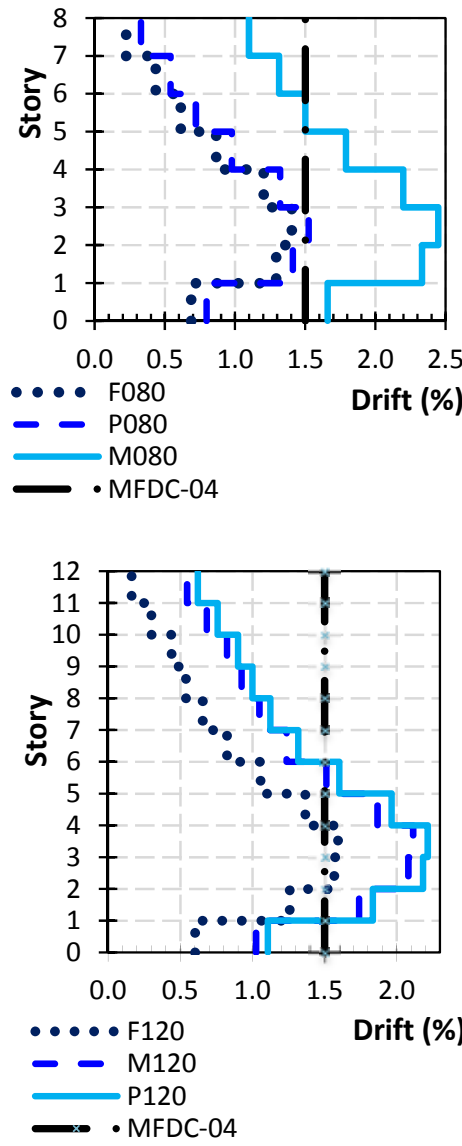

1-braced bay

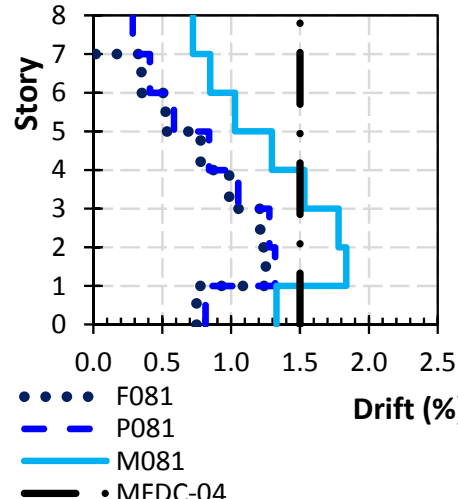

a) 8-story frames

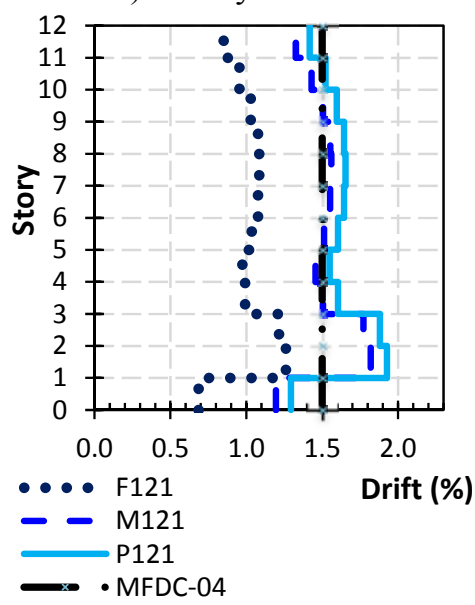

b) 12-story frames
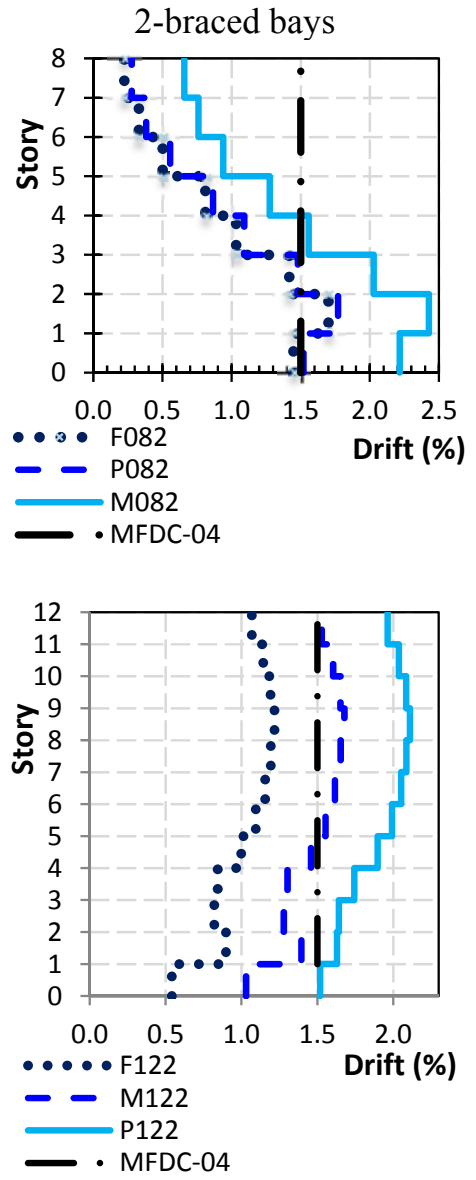

Figure 9. Deformation Demands at the Collapse Mechanism

\section{DUCTILITY AND OVERSTRENGTH CAPACITIES}

Ductility $\mu=\delta_{u} / \delta_{y}$ and overstrength capacities $\Omega=V_{u} / V_{y}$ were computed from pushover curves (Figure 4). The results for the 12-story frames are shown in Table 4.

The end of the elastic linear region are related with global drifts equal to $0.31 \%$ for the F122 and M122 models and $0.45 \%$ for the P122 model (Table 4, Figure 5b). Since the yielding drifts are related to the first non-linear step, the inelastic response appears sooner in fixed base and mat foundation than for the pile foundation system.

According to the results (Table 4), a dependency between the amount of braced bays (frame stiffness) and the ductility and overstrength capacities was noted. Stiffer frames (F122, P122 and M122) are related with the largest inelastic incursion. This trend does not depend on the base condition and might be simply due to the structural redundancy of each frame. 
Table 4. Ductility and Overstrength Developed by the Studied Frames

\begin{tabular}{llcccccc}
\hline $\begin{array}{c}\text { Boundary } \\
\text { condition }\end{array}$ & Model & $\begin{array}{c}\text { Yielding } \\
\text { drift } \\
\delta_{y}(\%)\end{array}$ & $\begin{array}{c}\text { Final } \\
\text { drift } \\
\delta_{u}(\%)\end{array}$ & $\begin{array}{c}\text { Ductility } \\
\mu\end{array}$ & $\begin{array}{c}\text { Shear at } \\
\text { yielding } \\
V_{y}(\mathrm{kN})\end{array}$ & $\begin{array}{c}\text { Final } \\
\text { shear } \\
V_{u}(\mathrm{kN})\end{array}$ & $\begin{array}{c}\text { Overstrength } \\
\text { Fixed }\end{array}$ \\
\hline \multirow{4}{*}{ F120 } & 0.51 & 0.86 & 1.69 & 2,163 & 2,644 & 1.22 \\
& $\mathrm{~F} 121$ & 0.41 & 1.02 & 2.49 & 5,046 & 8,891 & 1.76 \\
& $\mathrm{~F} 122$ & 0.31 & 1.01 & 3.26 & 6,248 & 14,658 & 2.35 \\
\hline \multirow{5}{*}{ Flexible } & $\mathrm{P} 120$ & 0.52 & 0.93 & 1.79 & 2,163 & 2,644 & 1.22 \\
& $\mathrm{P} 121$ & 0.41 & 1.05 & 2.56 & 5,046 & 8,891 & 1.76 \\
& $\mathrm{P} 122$ & 0.45 & 1.77 & 3.93 & 5,287 & 14,418 & 2.73 \\
& $\mathrm{M} 120$ & 0.52 & 0.92 & 1.77 & 2,163 & 2,644 & 1.22 \\
& $\mathrm{M} 121$ & 0.41 & 1.05 & 2.56 & 5,046 & 8,890 & 1.76 \\
& $\mathrm{M} 122$ & 0.31 & 1.02 & 3.29 & 6,248 & 14,658 & 2.35 \\
\hline
\end{tabular}

\section{INCREMENTAL DYNAMIC ANALYSES}

Incremental Dynamic Analysis (IDA) was performed on the 8- and 12-story frames to assess their performance against global collapse by instability. The IDA is a parametric analysis method that involves subjecting a structural model to ground motions that are scaled to multiple levels of intensity to produce curves of response parameters against intensity level (Vamvatsikos and Cornell [25]). The analysis was carried out for the motion recorded in Mexico City during the 1985 earthquake with magnitude 8.1 and peak amplitude of acceleration $0.17 \mathrm{~g}$ (Figure 10). The selected historical ground motion corresponds to the design spectrum, according to the MFDC-04 for the lake bed zone (soft clay).

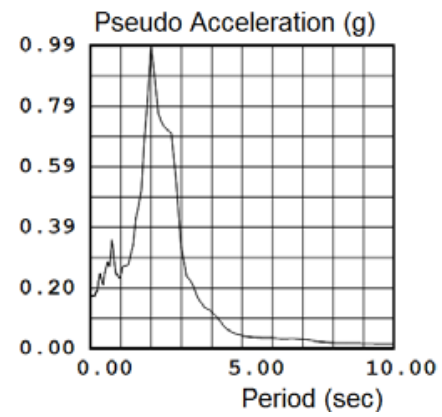

a) Response spectrum

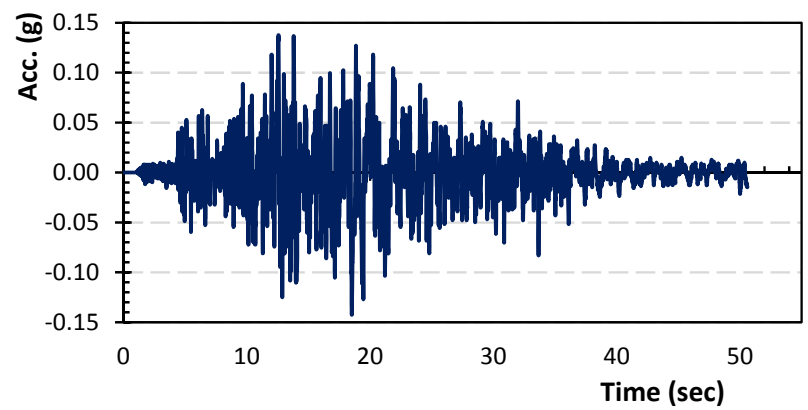

b) Acceleration time histories, component East-West

Figure 10. Motion Recorded in Mexico City during the 1985 Earthquake

The seismic behavior of the buildings was evaluated under IDA by examining the following response parameters:

a) Global drift (peak drift computed from the roof displacement $U_{T}$ over the height of the structure $H$ ).

b) Peak interstory drift obtained along the nonlinear analysis $\left(U_{i} / h\right)$.

c) The Drift Concentration Factor $D_{C F}$.

The peak global drift and the interstory drift angle allow the evaluation of the damage suffered for both the structural and non-structural elements. The drift concentration factor $D_{C F}$ is useful to evaluate the capacity of the structure to mitigate the soft story mechanism and to analyze how the structure mobilizes the energy dissipation capacity (Izvernari et al. [26]). It is defined as the ratio between the maximum peak story drift angle along the building height $U_{i} / h$ and the peak overall roof deformation angle $U_{T} / H$ (Eq. 6). 
$D_{C F}=\frac{U_{i} / h}{U_{T} / H}$

For steel frames, the value of $D_{C F}$ depends on the continuity of the columns and on the flexural stiffness. If the columns are continuous and infinitely rigid, $D_{C F}$ will be equal to unity. It means that all floors are equally deformed and story deformations are comparable to the average deformation of the building.

In the IDA procedure, a scaling factor was applied in order to increase the ground motion stepwise until collapse of the frame. The IDA curves (ground motion intensity against the maximum peak value) for 12-story frames with 1-braced bays (F121, P121 and M121) are shown in Figure 11. When drift values are compared (Figure 11a and 11b), frames with fixed base condition displayed a robust response; whereas, responses of models with SSI are similar between them. The model with a fixed base has a larger tendency to develop a soft story mechanism than the ones with flexible base (Figure 11c). In general, the response of F121 model (fixed base) envelops the response of flexible base models.

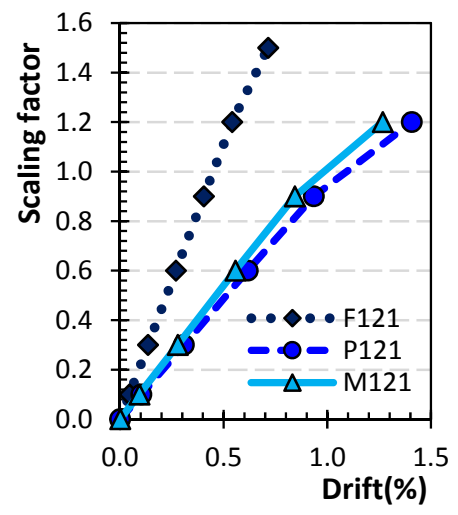

a) Global Drift

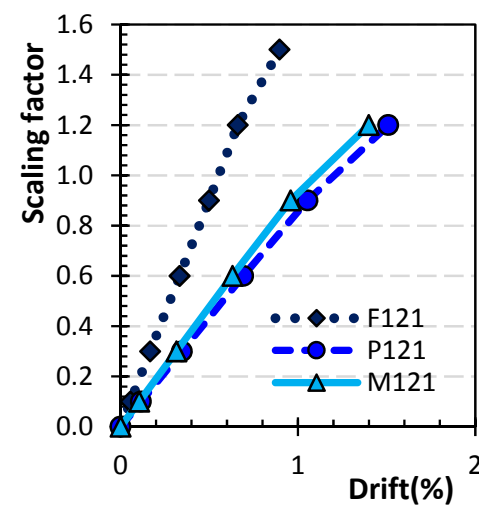

b) Maximum peak interstory drift

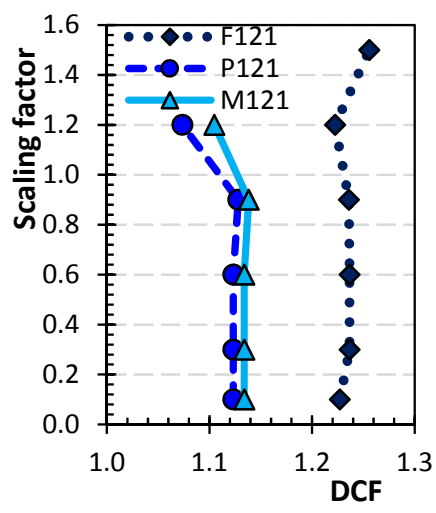

c) Drift concentration factor

Figure 11. Incremental Dynamic Analysis Curves for 1-braced Bays Frame

Moreover, IDA curves for 12-story frames with 2-braced bays (F122, P122 and M122) are shown in Figure 12. Here, the responses exhibit variations upon increasing ground motion amplitude up to dynamic instability by stepwise. The M122 curves generally exhibit a more stable response than the other models.

The F122 model (fixed base) does not completely envelop the response of the SSI models. This means that the fixed-base model might not be a conservative representation. In consequence, SSI might not be a beneficial effect on the seismic response of a structure, because of flexible base models develops a dynamic instability sooner than the one developed by the one with fixed-base, especially for the P122 model and a scaling factor equal to 1.5. Since this effect is developed only when the stiffer structures are compared, a relationship between the influence of the base flexibility and the lateral stiffness of the structure might be highlighted. 


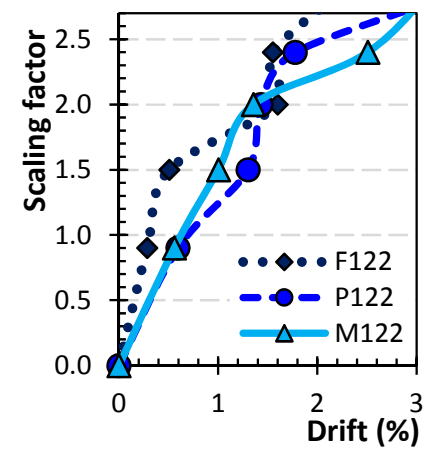

a) Global drift

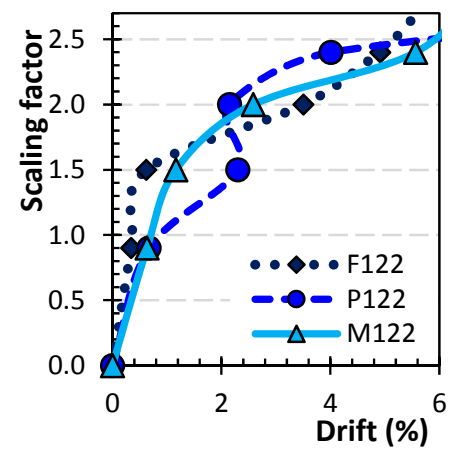

b) Maximum peak interstory drift

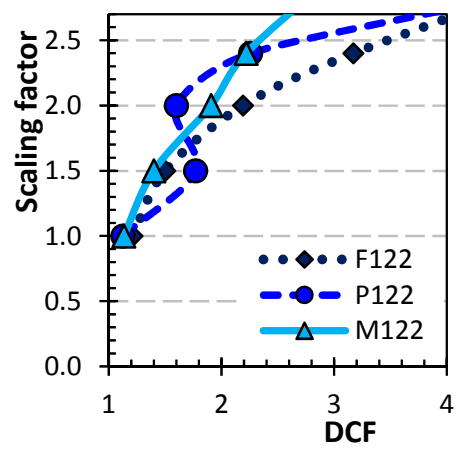

c) Drift Concentration Factor

Figure 12. Incremental Dynamic Analysis Curves for 2-braced Bays Frame

\subsection{Distribution of the Demands on the First Floor}

Efforts to assess the influence of SSI effects on the redistribution and maximum demands in columns were developed. The maximum bending moment, shear and axial force in columns A-5 (braced bay) and A-6 (unbraced bay) at the first floor of 12-story frames are shown in Figure 13 and 14 , respectively.

In column A-5 (Figure 13), peak demands of the bending moment and shear force of the flexible base models (M122 and P122) are enveloped by the demands of the fixed-base model (F122). This means that the rigid base analysis would be a conservative representation of the demands on the SSI models. However, the maximum axial load of P122 model exceeds the axial demands of the F122 model for a scaling factor equal to 1.5 (Figure 13c).

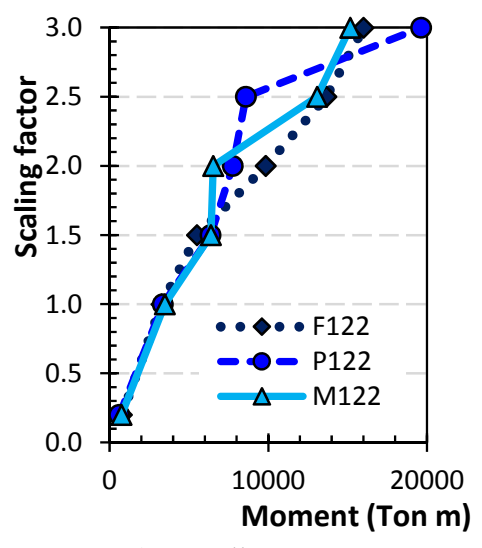

a) Bending moment

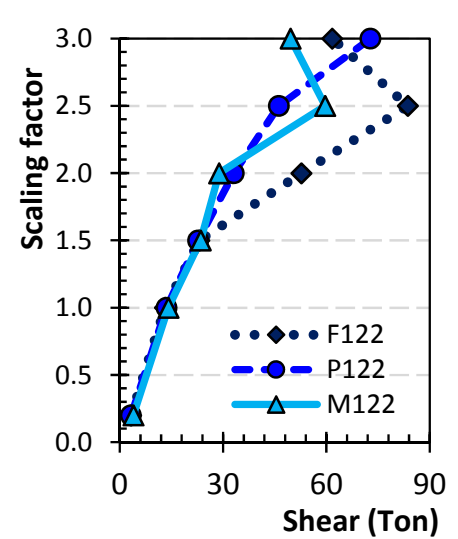

b) Shear

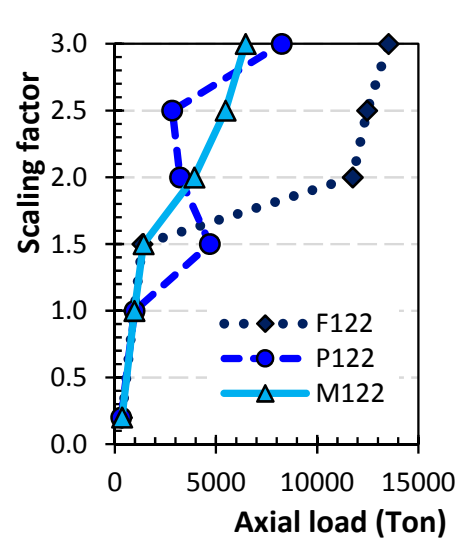

c) Axial force

Figure 13. Peak Demands under Incremental Dynamic Analysis of Column A-5 of 12-story Frames

Moreover, the same tendency was noted on demands of column A-6 (Figure 14). The F122 model (fixed base condition) is able to conservatively predict the magnitude of the peak demand of bending moment and shear force (Figure 13a and 13b). However, it is not a reliable representation of the axial load of the model with a piles foundation (P122, Figure 14c). Thus, the fixed-base model (F122) might estimate incorrectly the obtained axial loads when the SSI effect is accounted. 


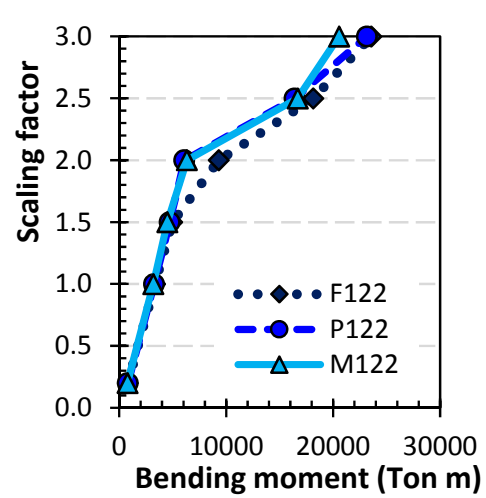

a) Bending moment

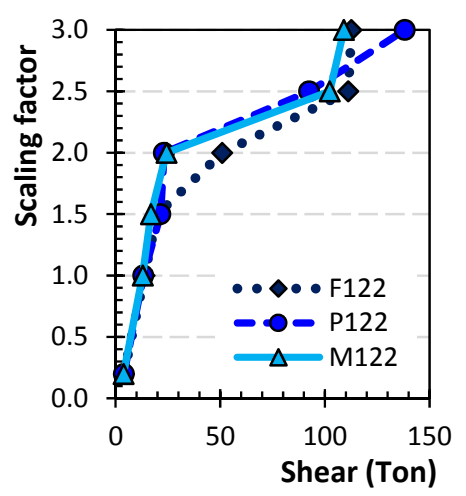

b) Shear

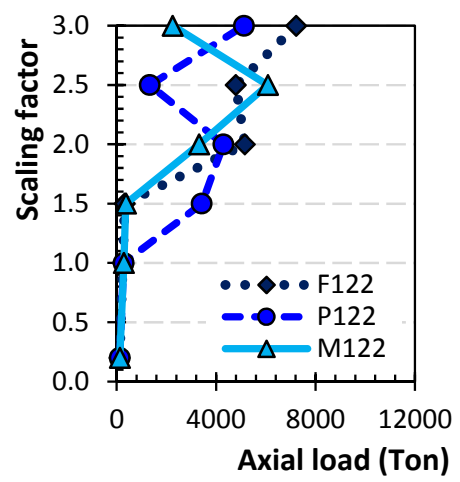

c) Axial load

Figure 14. Peak Demands under Incremental Dynamic Analysis of Column A-6 of 12-story Frames

\section{CONCLUSIONS}

In this paper, the inelastic responses of ductile steel frames of 8- and -12 regular buildings are evaluated. Models were analyzed under three boundary conditions: (i) fixed-base (no Soil-Structure Interaction), (ii) pile foundation and (iii) mat foundation. Buildings and foundations were designed according to the Mexico's Federal District Code with a ductility factor $\mu=3.0$ (the maximum allowed for these structures) and for soft-soil site condition (Lake zone).

Pushover analyses were carried out in order to evaluate the influence of the base flexibility on the ductility and overstrength capacities, displacements and collapse mechanisms. In addition, Incremental Dynamic Analyses were performed to assess the response based on the global drift, interstory drift, drift concentration factor and the peak demands in columns (bending moment, shear and axial load).

According to the results, the main contributions of the research are summarized as follow:

- In general, fixed-base models are stiffer than the flexible base models, when the deformation takes into account: a) the body deformations, b) the displacement associated with the foundation rocking and c) the base translation. However, in this study, it is reported that the group effect on piles might modify this trend for some particular conditions. In some cases, models with piles foundation were able to develop larger displacements than the ones with mat foundation. In others cases, models with piles became as stiff as the fixed-base models. So that, the stiffness of buildings with piles foundation is dependent not only of the base flexibility, but also of the specific design conditions, especially of the piles group effect.

- The displacement components of flexible base models (displacement $U_{F}$ and rocking $U_{\phi}$ ) represent about the 50 percent of the total displacement developed by the frames. Of them, the main contribution is related with the rocking effect $U_{\phi}$. No dependency was reported between this observation and the foundation system or building's height. Similar body deformations were developed regardless the modeled foundation system.

- The lateral stiffness is strongly dependent of the group effect on piles. For this reason, despite of the fact that the superstructure is regular and it was designed following rational analysis, for the studied buildings, it is not recommended to neglect the soil-structure interaction effect, especially for buildings with pile foundation system. 
- According to the results of incremental dynamic analysis, the axial load demands in the columns of the models with pile foundation exceed the ones developed by the fixed-base models for a range of the scaling factor. Fixed-base models might be an unconservative representation of the demands in flexible base models, despite of the fact that the peak demand of bending moment and shear force are acceptably enveloped by the response of the fixed-base model.

- For practical purposes, similar results were obtained in terms of collapse mechanisms and ductility and overstrength capacities, regardless the base foundation.

\section{REFERENCES}

[1] MFDC, Mexico's Federal District Code, Gaceta Oficial del Departamento del Distrito Federal. 2004, October (in Spanish).

[2] ASCE/SEI 7-05, Minimum Design Loads for Buildings and Other Structures, American Society of Civil Engineers, 2005.

[3] Ganjavi, B. and Hao, H., "A Parametric Study on the Evaluation of Ductility Demand Distribution in Multi-degree-of-freedom Systems Considering Soil-structure Interaction Effects", Engineering Structures, 2012, Vol. 43, pp. 88-104.

[4] Tapia-Hernández, E. and Tena-Colunga, A., "Code-Oriented Methodology for the Seismic Design for Regular Steel Moment Resisting Braced Frames”, Earthquake Spectra Journal, 2014, Vol. 3, No. 4, pp. 1683-1709.

[5] Moghaddam, H. and Hajirasouliha, I., "Fundamentals of Optimum Performance-Based Design for Dynamic Excitations”, Scientia Iranica, 2005, Vol. 12, No. 4, pp. 368-378.

[6] Aviles, J. and Perez-Rocha, L.E., "Use of Global Ductility for Design of Structure-foundation Systems", Soil Dynamic Earthquake Engineering, 2011, Vol. 31, No. 7, pp.1018-1026.

[7] Wolf, J.P., "Dynamic Soil-Structure Interaction", Prentice-Hall: New Jersey, 1985.

[8] Rosenblueth, E. and Reséndiz, D., "Disposiciones Reglamentarias de 1987 para tener en cuenta Interacción Dinámica Suelo-estructura", Research Report, 1988, No. 509, Universidad Nacional Autónoma de México (in Spanish).

[9] Avilés, J. and Pérez-Rocha, L.E., "Soil-structure Interaction in Yielding Systems", Earthquake Engineering and Structural Dynamics, 2005, No. 32, pp. 1749-1771.

[10] Tabatabaiefar, H.R., Samali, B. and Fatahi, B., "Effects of Dynamic Soil-Structure Interaction on Inelastic Behaviour of Mid-Rise Moment Resisting Buildings on Soft Soils", Proceedings of the Australian Earthquake Engineering Society Conference. Perth, Western Australia, 2010, pp. 1-11.

[11] Sáez, E., López-Cabellero, F. and Modaressi-Farahamand-Razavi, A., "Inelastic Dyanamic Soil-structure Interaction Effects on Moment-resisting Frame Buildings", Engineering Structures, 2013, Vol. 51, pp. 166-177.

[12] Ganjavi, B. and Hao, H., "Elastic and Inelastic Response of Single- and Multi-degree-of-freedom Systems Considering Soil Structure Interaction Effects", Proceeding of the Australian Earthquake Engineering Society Conference, Barossa Valley, South Australia, 2011, pp. 1-9.

[13] Barcena, A. and Esteva, L., "Influence of Dynamic Soil-structure Interaction on the Nonlinear Response and Seismic Reliability of Multistory Systems", Earthquake Engineering and Structural Dynamic, 2007, Vol. 36, No. 3, pp. 327-346.

[14] Raychowdhury, P., "Seismic Response of Low-rise Steel Moment Frame (SMRF) Buildings Incorporating Nonlinear Soil-structure Interaction (SSI)", Engineering Structures, 2011, Vol. 33, pp. 958-967. 
[15] Fernandez-Sola, L.R., Dávalos-Chavez, D. and Tapia-Hernandez, E., "Influence of the Dynamic Soil Structure Interaction on the Inelastic Response of Steel Frames: Proceedings of the 10th National Conference in Earthquake Engineering, Anchorage, AK. 2014, pp. $1-11$.

[16] Tapia-Hernández, E., "Comportamiento de Edificios Regulares Estructurados Con Marcos Dúctiles de Acero Con Contraventeo Concéntrico En Suelos Blandos", Ph.D. Thesis, 2011, Universidad Autónoma Metropolitana Azcapotzalco, available at http://posgradoscbi.azc.uam.mx/descargas/Tesis_ies_2011_TapiaHernandezEdgarUAM-A.p df (in Spanish).

[17] Tapia-Hernández, E. and Tena-Colunga, A., "Lateral Demands of Steel Moment Resisting Concentrically Braced Frames in Soft Soils", Proceedings of the XV World Conference on Earthquake Engineering, Lisbon, Portugal, 2012, ID. 1614. pp. 1-10.

[18] Dávalos D., "Influencia de la interacción dinámica suelo estructura en el comportamiento estático no lineal de marcos de acero con y sin contravientos", Master Thesis, 2013, Universidad Autónoma Metropolitana Azcapotzalco, México (in Spanish).

[19] Jafarzadeh, F. and Asadinik, A., "Dynamic Response and Impedance Functions of Foundation Resting on Sandy Soil using Physical Model Tests", Proceedings of the XIV World Conference on Earthquake Engineering. Beijing, China, 2008, pp. 1-8.

[20] Novak, M., Sheta, M., El-Hifnawy, L., El-Marsafawi, H. and Ramadan, O., "DYNA5: A Computer Program for Calculation of Foundation Response to Dynamic Loads", Geotechnical Research Centre, 2005, The University of Western Ontario.

[21] Prakash, V., Powell, G.H. and Fillipou, F., "DRAIN-2DX: Base Program User Guide", Report No. UCB/SEMM-92/29, 1992, Department of Civil Engineering, University of California at Berkeley.

[22] Dobry, R. and Gazetas, G., "Simple Method for Dynamic Stiffness and Damping of Floating Pile Groups", Geotechnique, 1988, Vol. 38, No. 4, pp. 557-574.

[23] Lacerte, M. and Tremblay, R., "Making Use of Brace Overstrength to Improve the Seismic Response of Multistory Split-X Concentrically Braced Steel Frames", Canadian Journal of Civil Engineering, 2006, 33, pp. 1005-1021.

[24] Tapia-Hernández, E. and Tena-Colunga, A., "Diseño sísmico de marcos de acero contraventeados. Parte 1: Recomendaciones de Diseño", Revista de Ingeniería Sísmica, 2013, 88, pp. 43-68. dx.doi.org/10.18867/2013-RIS-88-3 (in Spanish).

[25] Vamvatsikos, R. and Cornell, A., "Incremental Dynamic Analysis", Earthquake Engineering and Structural Dynamics, 2002, Vol. 31, pp. 492-514.

[26] Izvernari, C., Lacerte, M. and Tremblay, R., "Seismic Performance of Multi-storey Concentrically Braced Steel Frames Designed According to the 2005 Canadian Seismic Provisions", Proceedings of the IX Canadian Conference on Earthquake Engineering, Ottawa, Canada. 2007, pp. 1-10. 